\title{
Peningkatan Kemampuan Komunikasi Matematis Siswa dalam Pembelajaran Daring Menggunakan Media Video Pembelajaran
}

\author{
Retno Dumila ${ }^{1, a}$, D Hardianti $1^{2, b}$, Noprisa ${ }^{2, c}$ \\ Prodi Pendidikan Matematika, FKIP, Universitas Muhammadiyah Lampung, \\ Jl. Zainal Abidin Pagar Alam No. 14, Bandar Lampung 35142 \\ e-mail: aretnodumila1@gmail.com, bhardiantidesrina@gmail.com, \\ cnoprisaica@gmail.com
}

\begin{abstract}
This study aims to determine the improvement of students' mathematical communication skills in online learning by using instructional video media. The study used a quasi-experimental method with a pretest-posttest control group design. The research subjects were students of class VIII in a private Junior High School in Bandar Lampung City. There are two classes in this study, namely the experimental class consisted of 33 students and the control class consisted of 33 students. The experimental class received online learning using instructional video media, while the control class used the method without giving intructional videos. The research instrument used a mathematical communication ability test. The results showed that the inprovement in mathematical communication skills in the experimental class was better than the control class.
\end{abstract}

Keywords : Mathematical Communication, Intructional Video Media

\begin{abstract}
Abstrak
Penelitian ini bertujuan untuk mengetahui peningkatan kemampuan komunikasi matematis siswa dalam pembelajaran daring dengan menggunakan media video pembelajaran. Penelitian menggunakan metode kuasi eksperimen dengan desain pretest-postes control group. Subjek penelitian adalah siswa kelas VIII di satu SMP Swasta di Kota Bandar Lampung. Terdapat dua kelas dalam penelitian ini yaitu kelas eksperimen sebanyak 33 siswa dan kelas kontrol sebanyak 33 siswa. Pada kelas ekperimen memperoleh pembelajaran daring menggunakan media video pembelajaran sedangkan kelas kontrol menggunakan metode tanpa video pembelajaran. Instrumen penelitian menggunakan tes kemampuan komunikasi matematis siswa dengan mengacu pada indikator kemampuan komunikasi matematis. Hasil menunjukkan peningkatan kemampuan komunikasi matematis pada kelas eksperimen lebih baik dari kelas kontrol.
\end{abstract}

Kata kunci : Komunikasi Matematis, Media Video Pembelajaran 


\section{PENDAHULUAN}

Hakikatnya manusia hidup untuk belajar dari lahir sampai liang lahat. Pendidikan merupakan dasar atau pondasi untuk memulai kehidupan. Sebagai manusia yang bijak tentu perlu mengedepankan pendidikan agar menjadi manusia yang berilmu. Pendidikan juga penting bagi siswa sebagai acuan dalam menjalani kehidupan agar menjadi manusia yang cerdas dan berakhlak. Salah satunya adalah pendidikan matematika. [1] berpendapat bahwa matematika adalah proses berpikir, mengorganisasikan, menalar, dan matematika adalah bahasa yang didefinisikan secara cermat, dan direpresentasikan dengan jelas, dan akurat, menggunakan simbol dan lebih diucapkan, lebih dalam bentuk. Melihat dari hal ini, matematika dapat mengasah pola berpikir siswa dalam menghadapi suatu masalah yang jelas sangat berguna untuk di implementasikan saat sudah terjun kemasyarakat.

Penyampaian pelajaran matematika pada saat ini tentu menemui kesulitan yang sungguh berarti, saat ini seluruh dunia dilanda pandemi Coronavirus Diseas (Covid-19). Untuk mencegah penyebaran penyakit dan penyebaran COVID-19, Departemen Pendidikan dan Kebudayaan telah mengumumkan Kebijakan Pembatasan. No. 4 Tahun 2020 mengacu pada pelaksanaan tahap kedua, mengatakan bahwa sekolah dibangun dari rumah melalui berbagai program. Salah satu langkah yang dilakukan untuk memajukan berlangsungnya kegiatan belajar di sekolah dalam hal ini adalah pembelajaran dalam jaringan (daring). Menurut Moore, dkk (2011) menjelaskan bahwa pembelajaran daring adalah pembelajaran yang memakai koneksi dan akses internet sehingga bersifat fleksibel.

Pelaksanaan pembelajaran secara daring tentu menjadi solusi untuk pelaksanaan kegiatan belajar mengajar di era pandemi covid-19. Pembelajaran daring memberi kesepatan siswa maupun guru untuk melaksanakan pembelajaran dari jarak jauh sehingga meminimalisir penularan covid-19 dan tetap melaksanakan kewajiban sebagai pendidik maupun siswa. Pembelajaran daring sebagai solusi untuk 
kegiatan belajar dimasa pandemi tentu memiliki bentuk dan struktur yang berbeda dari pembelajaran biasa.

Pada pembelajaran daring semua kegiatan dilakukan tanpa tatap muka baik pemberian materi pelajaran, penugasan, pengambilan nilai ulangan semua dilaksanakan melalui daring. Penggunaan berbagai aplikasi seperti Google Classroom, Google Meet, Edmudo, Rubelmu dan Zoom dapat digunakan untuk menunjang berlangsungnya pembelajaran daring.

Kegiatan belajar mengajar pada umumnya dapat dilakukan tanpa kendala yang berarti karena dilakukan secara tatap muka langsung. Lain halnya dengan pembelajaran daring yang saat ini telah berlangsung. Dimana dalam pembelajaran daring siswa dan guru berada diruang dan waktu yang terpisah oleh jarak. Hal ini sebagai konsekuensi dari penyebaran Covid-19 di seluruh dunia sehingga guru dan siswa tidak diperbolehkan untuk terlibat dalam kegiatan belajar mengajar secara langsung. Kegiatan yang dilakukan tanpa tatap muka secara langsung tentu menimbulkan banyak sekali masalah terutama masalah mengenai penyampaian materi kepada siswa. Pada sesi tatap muka siswa dan guru dapat berkomunikasi secara langsung saat pembelajaran. Siswa dapat bertanya langsung, sehingga guru dapat memberikan solusi sesuai dengan apa yang ditanyakan oleh siswa. Namun lain halnya dengan pembelajaran daring saat ini, guru lebih memilih untuk memberikan ringkasan materi secara singkat dan meminta siswa untuk membaca sendiri materi.

Keterbatasan waktu yang tersedia membuat guru tidak memungkinkan untuk standby sepanjang hari untuk melayani siswa. Sedangkan tidak semua siswa dapat mengikuti pembelajaran daring di jam sekolah, karena siswa dapat menggunakan smartphone saat orang tua sudah kembali dari bekerja.

Pembelajaran yang dilaksanakan dengan cara siswa diminta untuk mempelajari materi secara mandiri. Pembelajaran seperti ini tentu akan mempengaruhi kemampuan matematis siswa karena siswa enggan bertanya pada guru mengenai materi yang disampaikan. Untuk mengatasi permasalahan seperti ini diperlukan suatu perubahan dalam 
penyampaian pembelajaran. Perubahan ini akan menuntut lebih banyak siswa untuk tertarik dan mengajukan pertanyaan kepada guru tentang apa pun yang mereka tidak mengerti.

Penggunaan media pembelajaran merupakan salah satu unsur yang berperan penting dalam terciptanya lingkungan belajar yang positif. Media pembelajaran pada hakekatnya adalah alat yang digunakan untuk menyampaikan materi pelajaran. Danim (1995) berpendapat bahwa penjangkauan pendidikan adalah seperangkat alat yang digunakan oleh guru untuk bertukar informasi dengan siswa. Media pendidikan memiliki banyak peran, yaitu fungsi konten, komunikasi, motivasi, kesadaran diri dan kesetaraan (Sanjaya 2014). Melihat kinerjanya, ketersediaan media pembelajaran seharusnya menjadi faktor penting dalam penggunaan pendidikan online selama masa krisis ini. Memilih materi pelajaran yang tepat sangatlah penting.

Media pembelajaran yang dapat diaplikasikan dalam pembelajaran daring antara lain MS. Power Point dan video pembelajaran. Pemilihan kedua media ini didasarkan dengan kondisi saat ini yang tidak memungkinkan guru dan siswa untuk bertatap muka secara langsung. Pemberian pembekalan dari perangkat elektronik merupakan kenyataan dalam penyampaian materi pendidikan, namun hanya dengan menempatkan denah elektronik, para siswa tidak memahami informasi yang disajikan. Penggunaan video pelajaran yang isinya seperti pembelajaran di kelas akan membuat siswa lebih paham tentang materi yang diberikan oleh guru, bahkan jika itu hanya pengalaman satu arah, tidak terpengaruh oleh siswa selama video diputar.

Hardianti dan Asri (2017) menyampaikan bahwa dengan adanya video pembelajaran siswa dapat mengefisiensikan waktu untuk belajar, memperoleh pengalaman baru dalam belajar, informasi lebih akurat dan menarik. Melihat pendapat ini penggunaan video pembelajaran 
sangatlah berpengaruh terhadap berlangsungnya pembelajaran daring karena keefektifannya sebagai media pembelajaran.

Matematika merupakan mata pelajaran yang dalam prakteknya memiliki banyak kemampuan yang dapat dijunjung tinggi oleh siswa. Salah satunya adalah kemampuan komunikasi matematis. Penggunaan video pembelajaran merangsang siswa agar lebih memahami materi yang disampaikan. Mempelajari matematika, tentu hal ini dapat merangsang siswa untuk melakukan komunikasi secara matematis. Pada setiap materi dalam pelajaran matematika memiliki ciri khas dalam mengkomunikasikannya, komunikasi matematis perlu dikuasai siswa untuk memahami materi yang dipelajari. Kemampuan komunikasi matematis diperlukan untuk membiasakan siswa dapat mandiri dalam memahami persoalan matematika. Hal ini sesuai dengan tujuan dalam melaksanakan pembelajaran matematika, salah satu tujuan belajar matematika adalah siswa dapat mengkomunikasikan gagasan dengan kata, simbol,

Greenes (1996) yang mengatakan Komunikasi matematis adalah: (1) potensi terbesar siswa mengembangkan konsep dan strategi matematika, (2) landasan bagi kesuksesan siswa dalam eksplorasi dan penemuan penelitian dan pengembangan matematika, (3) di mana siswa berkomunikasi dengan rekan-rekan mereka untuk menerima informasi, berbagi pemikiran dan menemukan, berbagai ide, penilaian dan saran untuk mempercayai orang lain. Viseu dan Oliveira (2012) mengutarakan melalui komunikasi siswa memperoleh rangsangan untuk berbagai konsep, gagasan dan solusi matematika. Berdasarkan pendapat diatas dapat ditarik kesimpulan bahwa kemampuan mengomunikasikan persoalan matematika sangat perlu dimiliki oleh siswa, karena dengan memiliki kemampuan komunikasi matematis 
siswa dapat menyampaikan permasalahan matematis dengan benar, sehingga mampu menentukan solusi matematika dengan benar.

Hasil observasi yang pernah dijalankan oleh peneliti di satu SMP Swasta di Bandar Lampung, diperoleh informasi bahwa banyak siswa mengalami kendala dalam mengkomunikasikan persoalan matematika kedalam bahasa matematis. Tentu persoalan ini berakibat siswa tidak dapat merumuskan konsep dan strategi matematis, sehingga siswa gagal menyelesaikan persoalan matematis. Majid, (2020) dalam penelitiannya, siswa yang memiliki komunikasi matematis sedang, mampu memenuhi 4 indikator kemampuan komunikasi matematis sedangkan siswa dengan kemampuan komunikasi rendah, hanya dapat memenuhi 3 indikator saja. Merujuk dari hasil penelitiannya, Rifda menyampaikan bahwa perlu adanya peningkatan kemampuan komunikasi matematis siswa.

Berdasarkan pemaparan yang disampaikan pada latar belakang, kemampuan mengomunikasikan matematis mutlak perlu dimiliki oleh siswa. Oleh karena, pentingnya kemampuan komunikasi matematis, maka diperlukan suatu upaya untuk mengatasi permasalahan diatas. Salah satu upaya yang dapat dilakukan adalah dengan melakukan pembelajaran menggunakan media video pembelajaran. Melihat kedua aspek ini peneliti tertarik untuk melakukan penelitian tentang:" Peningkatan Kemampuan Komunikasi Matematis Siswa dalam Pembelajaran Daring Menggunakan Media Video Pembelajaran”.

\section{METODE PENELITIAN}

Penelitian dilaksakan di satu SMP Swasta di Bandar Lampung. Populasi dalam penelitian ini adalah siswa kelas VIII semester genap tahun pelajaran 2020-2021. Kelas VIII di sekolah ini terdistribusi dalam enam kelas (VIII A- VIII F) . Pengambilan sampel menggunakan tehnik Purposive Sampling pengambilan sampel dengan ketentuan khusus. diperoleh kelas VIII C sebagai kelas eksperimen dan kelas VIII D sebagai kelas kontrol. Banyaknya siswa pada masing-masing kelas 


\section{Hipotenusa}

adalah 33 siswa. Tujuan dari penelitian ini adalah untuk mengetahui bagaimana meningkatkan kemampuan mengomunikasikan persoalan matematika siswa dalam pembelajaran online melalui penggunaan video yang lebih tinggi dari kemampuan komunikasinya matematika menggunakan pedoman pembelajaran di kelas VIII di sebuah SMP Swasta di Bandar Lampung.

Penelitian ini menggunakan penelitian kuasi eksperimen yang terdiri dari dua variabel. Variabel bebasnya adalah video pembelajaran sedangkan variabel terikatnya adalah kemampuan komunikasi matematis. Desain penelitian adalah pretest-posttest control group design sebagaimana yang dikemukakan oleh Noor (2016) yang disajikan sebagai berikut.

\begin{tabular}{cccc} 
Eksperimen & $\mathrm{O}_{1}$ & $\mathrm{X}_{1}$ & $\mathrm{O}_{2}$ \\
\cline { 2 - 4 } Kontrol & $\mathrm{O}_{1}$ & $\mathrm{X}_{2}$ & $\mathrm{O}_{2}$
\end{tabular}

\section{Keterangan:}

$\mathrm{O}_{1}$ : Pretes kemampuan komunikasi matematis siswa

$\mathrm{O}_{2}$ : Postes kemampuan komunikasi matematis siswa

$X_{1}$ : Pembelajaran menggunakan media videopembelajaran

$\mathrm{X}_{2}$ : Pembelajaran tanpa video pembelajaran

Teknik pengumpulan data menggunakan tes uraian. Pengujian menggunakan tes bertujuan untuk mengukur kemampuan sisawa mengomunikasikan persoalan matematis yang diperoleh siswa sebelum (pretest) dan sesudah diberi perlakuan (posttest) pada kelas eksperimen dan kelas kontrol. Instrumen yang digunakan dalam penelitian ini berupa tes kemampuan komunikasi metematis yang terdiri dari pretest dan posttest. Materi yang digunakan untuk penelitian adalah Bangun Ruang dan Sisi Datar. Tes yang diberikan pada setiap kelas pretest dan posttest adalah soal yang sama. Pengumpulan data yang akurat dilakukan dengan menggunakan tes yang mempenuhi persyaratan tes yang baik, yaitu validitas tes, 


\section{Hipotenusa}

Journal of Research Mathematics Education VOL. 4 NO.2 2021

reliabilitas, daya pembeda, dan tingkat kesukaran (Arifin, 2017). Jika data yang diperoleh dari hasil pengujian benar dan sesuai maka instrumen yang digunakan tersebut juga sesuai/valid. Hasil pengujian menunjukkan bahwa semua soal yang diujikan valid. Reliabilitas merupakan kesesuaian antara soal dengan materi yang disampaikan. Nilai reliabilitas tes kemampuan komunikasi matematis menunjukkan angka 0,749, dengan demikian butir soal memiliki reliabilitas tinggi. Hasil perhitungan menunjukkan semua soal memiliki daya pembeda dengan iterpretasi sangat baik. Hasil uji menunjukkan soal memiliki tingkat kesukaran yang berbeda-beda.

\section{HASIL DAN PEMBAHASAN}

Pembelajaran yang berlangsung pada kelas eksperimen dan kelas kontrol secara umum mengkondisikan siswa untuk belajar dengan mengutamakan kemampuan komunikasi matematis. Pemberian tugas baik kelas ekeperimen maupun kelas kontrol adalah soal yang sama, dimana soal tersebut merangsang siswa untuk mengomunkasikannya secara matematis. Berikut jawaban salah satu siswa sebelum dan sesudah diberi perlakuan.

3. Ani ingin melaplsi sebuah kotak berbeniwk kubus dengan kertas yang memiliki panjang $22 \mathrm{~cm}$ dan lebar $15 \mathrm{~cm}$. Jika katak memiliki panjang rusuk $7 \mathrm{~cm}$. Cukup atau kidakkah kertas tib unituk melapisi kotak ?

luas kotak $=6 \times 7 \times 7=294 \mathrm{~cm}^{2}$

Persedlaan kertasnya $22 \times 15=330 \mathrm{~cm}^{2}$

Berarti ani tidat cukup kertasnya unwk melapisi kutak.

Gambar 3.1 Jawaban Pretes Siswa 


\section{Hipotenusa}

Pada gambar diatas terlihat bahwa sebelum diberi perlakuan siswa masih kurang paham dan kemampuan komunikasi matematisnya belum baik. Setelah diberlakukan pembelajaran menggunakan media video, siswa tersebut menunjukkan peningkatan kemampuan komunikasi matematis. Berikut ini adalah tanggapan siswa sesudah mengikuti pembelajaran menggunakan media video pembelajaran,

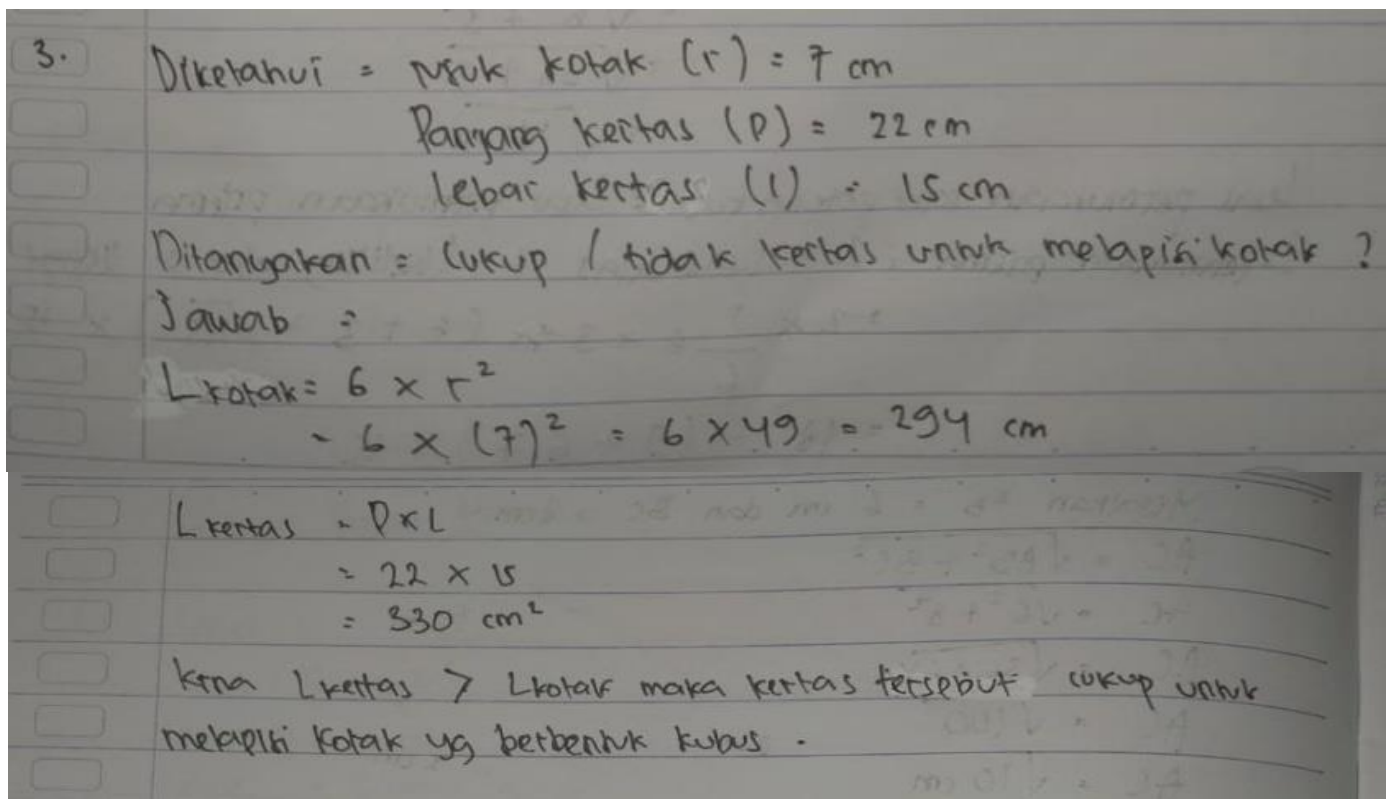

Gambar 3.2 Jawaban Postes Siswa

Terlihat pada lembar jawaban postes siswa dapat mengerjakan persoalan dengan baik. Siswa juga mampu mengomunikasikan persoalan dengan tepat. Dimana siswa tau langkah apa yang harus dikerjakan, mulai dari mencari pendekatan yang sesuai untuk menyelesaikan soal. Hal ini sesuai dengan indikator kemempuan komunikasi matematis yaitu ekperesi matematika dimana siswa mampu menyelesaikan persoalan dengan ide yang tepat. Melihat gambar jawaban pretes dan postes terlihat jelas peningkatan komunikasi matematis siswa tersebut.

Hasil analisis data kemapuan komunikasi matematis siswa, pembelajaran daring menggunakan video pembelajaran dapat 
meningkatkan kemampuan siswa dalam mengomunikasikan persoalan matematis. Uji analisis juga mendungkung adanya peningkatan peringkat kemampuan siswa dalam mengomunikasikan persoalan matematis pada kelas eksperimen menunjukkan hasil lebih tinggi dari pada kelas kontrol. Analisis nilai pretes kemampuan komunikasi matematis siswa memperlihatkan hasil kemampuan awal siswa dalam mengomunikasikan pesoalan matematis pada kelas eksperimen dan kelas kontrol cenderung sama. Data statistik deskriptif pretes menunjukkan nilai rata-rata pada kelas eksperimen yaitu 31,35 dan kelas kontrol 24,72. Setelah diberikan perelakuan yaitu menerapkan video pembelajaran pada kelas ekeperimen dan ringkasan materi pada kelas kontrol diperoleh data nilai postes kemampuan siswa mengomunikasikan persoalan matematis pada akhir pembelajaran. Hasil uji statistik rata-rata nilai postes menunjukkan nilai 77,27 pada kelas eksperimen sedangkan 51,61 untuk kelas kontrol. Keduanya menunjukkan hasil yang jauh bebeda antara kemampuan siswa mengomunikasikan persoalan matematis di kelas eksperimen dan kelas kontrol. Rata-rata skor yang diperoleh kelas eksperimen lebih tinggi dari kelas kontrol. Data rata-rata pretes dan postes tersaji dalam grafik berikut,

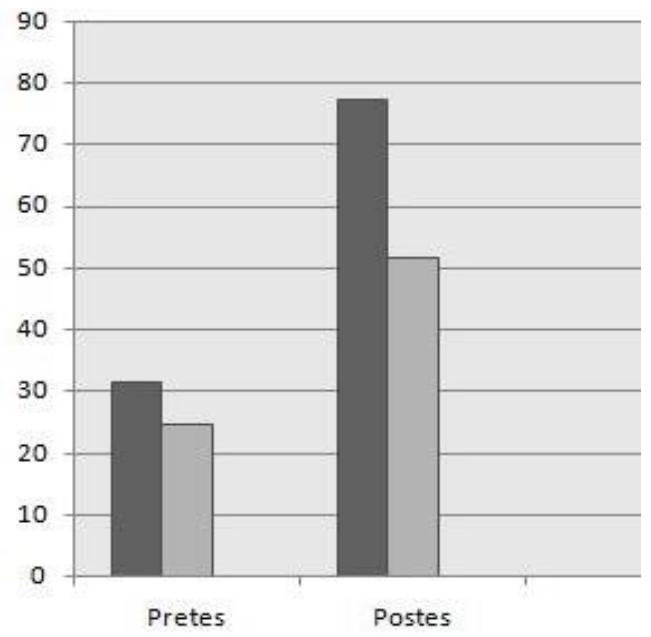

Eksperimen

$\square$ Kontrol

Gambar 3.3. Grafik Rata-Rata Skor Pretes Dan Postes Kemampuan Komunikasi Matematis Siswa 
Berdasarkan data pretes dan postes serta garafik diatas terlihat adanya peningkatan kemampuan siswa dalam mengomunikasikan persoalan matematis, dimana peningkatan pada kelas eksperimen lebih baik dari kelas kontrol. Selaras dengan hasil pretes dan postes, nilai $N$-Gain juga menunjukkan hasil yang tidak berbeda. Pada kelas eksperimen nilai $N$-Gain adalah 0,6702 dan pada kelas kontrol 0,3430 dimana kedua kelas temasuk pada kategori sedang. Hasil $N$-Gain dapat dilihat pada grafik berikut,

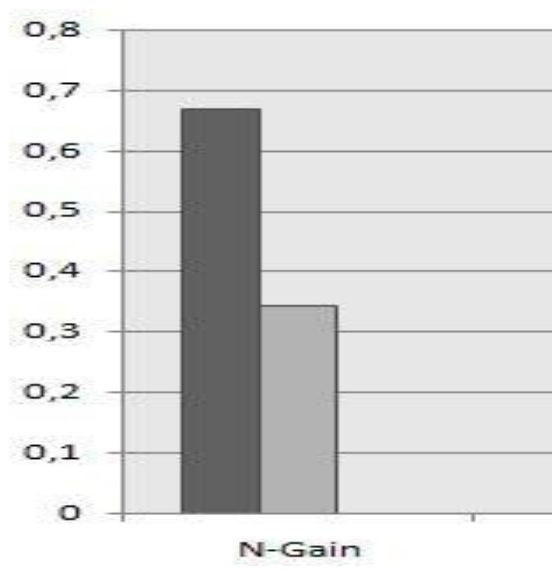

Eksperimen

$\square$ Kontrol

Gambar 3.4. Grafik N-Gain Kemampuan Komunikasi Matematis Siswa

Uji perbedaan rata-rata nilai $N$-Gain menunjukkan hasil ratarata skor peningkatan kemampuan siswa mengomunikasikan matematika yang mengikuti pembelajaran menggunakan video pembelajaran lebih baik dari rata-rata skor peningkatan kemampuan siswa mengomunikasikan matematika yang mengikuti pembelajaran tanpa video. Berdasarkan uraian diatas dapat diambil sebuah kesimpulan pembelajaran daring menggunakan media video pembelajaran dapat meningkatkan kemampuan siswa dalam mengomunikasikan persoalan matematis dengan baik. Hal ini dikarenakan selama pelaksanaan pembelajaran menggunakan video pembelajaran dapat memancing siswa untuk melakukan interaksi 


\section{Hipotenusa}

Journal of Research Mathematics Education

VOL.4 NO.2 2021

dengan guru, seperti siswa mau bertanya mengenai materi yang disajikan

Hasil penelitian sejalan dengan beberapa penelitian terdahulu yang dilakukan oleh Nurrohma dan Purnomo (2020), Ferdianto (2016) serta, Nasution dan Hayati (2020). Penggunaan video pembelajaran untuk meningkatkan kemampuan siswa mengomunikasikan persoalan secara matematis juga dilakukan oleh peneliti terdahulu berikut adalah pemaparannya. Nurrohma dan Purnomo (2020) melakukan penelitian dengan tujuan untuk mengetahui efektivitas penggunaan video pembelajaran guna meningkatkan kemampuan siswa mengomunikasikan persoalan matematis. Penelitian tersebut memaparkan hasil peningkatan kemampuan siswa dalam mengomunikasi persoalsan secara matematis menggunakan video pembelajaran lebih baik dari kemampuan dalam mengomunikasikan persoalan matematis tanpa video pembelajaran.

Ferdianto (2016) menunjukkan bahwa pelaksanaan pembelajaran menggunakan media video dalam pemabahasan materi tabung dapat meningkatkan kemampuan siswa dalam mengomunikasikan pesoalan secara matematis dan meningkatkan aktivitas siswa selama pembelajaran berlangsung. Selaras dengan penelitian Ferdianto, Nasution dan Hayati (2020) menunjukkan peningkatan kemampuan siswa mengomunikasikan persoalan matematis dari siklus I rata-rata nilai sebesar 77 menjadi 91 pada siklus II.

\section{KESIMPULAN DAN SARAN}

\subsection{Kesimpulan}

Berdasarkan permasalahan, hasil analisis data dan pembahasan penelitian dapat diambil kesimpulkan peningkatan kemampuan siswa mengomunikasikan persoalan matematis dalam pembelajaran daring menggunakan media video pembelajaran lebih baik dari kemampuan 


\section{Hipotenusa}

Journal of Research Mathematics Education

sisawa mengomunikasikan persoalan secara matematis yang mengikuti pembelajaran daring tanpa video. Peningkatan kemampuan komunikasi matematis kelas eksperimen dan kelas kontrol jauh berbeda, dimana penigkatan kemampuan komunikasi kelas eksperimen lebih tinggi dari kelas kontrol.

\subsection{Saran}

Berdasarkan hasil penelitian dan kesimpulan, maka peneliti menyarankan hal-hal sebagai berikut:

\section{Bagi Guru}

Penggunaan media video pembelajaran untuk menyampaikan materi matematika dapat digunakan sebagai alternatif pelaksanaan pembelajaran daring. Namun untuk pelaksanaanya guru perlu mempersiapkan materi dan video yang menarik untuk siswa. Sehingga kemampuan siswa mengomunikasikan persoalan matematis dapat ditingkatkan.

\section{Bagi Peneliti Lebih Lanjut}

Untuk penelitian serupa atau penelitian lebih lanjut perlu mengetahui bagaimana dasar-dasar dalam pembuatan video pembelajaran agar memperoleh hasil yang maksimal. Penulis juga menyarankan untuk menggunakan pokok bahasan yang sama dalam mengukur kemampuan siswa dalam mengomunikasikan persoalan matematis. Melihat siswa yang tidak semua dapat hadir saat jam pelajaran maka peneliti selanjutnya perlu membuat kesepakatan dengan siswa mengenai ketepatan waktu pembelajaran sesuai jam yang sudah ditentukan.

\section{DAFTAR PUSTAKA}

[1] R. Johnson, Guideline for Teaching Mathematick. California: Wadswort publising company, Inc, 1972.

[2] J. L. Moore, C. Dickson-Deane, and K. Galyen, "e-Learning, online learning, and distance learning environments: Are they the same?," Internet High. Educ., vol. 
14, no. 2, pp. 129-135, 2011.

[3] S. Danim, Media Komunikasi Pendidikan. Jakarta: Bumi Aksara, 1995.

[4] H. Hardianti and W. K. Asri, "Keefektifan Penggunaan Media Video dalam Keterampilan Menulis Karangan Sederhana Bahasa Jerman Siswa Kelas XII IPA SMA Negeri 11 Makassar," Eralingua J. Pendidik. Bhs. Asing dan Sastra, vol. 1, no. 2, 2017.

[5] C. Greenes, "Investigations: Vehicles for learning and doing mathematics," $J$. Educ., vol. 178, no. 2, pp. 35-49, 1996.

[6] F. Viseu and I. B. Oliveira, "Open-ended tasks in the promotion of classroom communication in mathematics," Int. Electron. J. Elem. Educ., vol. 4, no. 2, pp. 287-300, 2012.

[7] R. N. Majid, “Analisis Kemampuan Komunikasi Matematis Peserta Didik Dalam Pembelajaran Menggunakan Daring." Universitas Pancasakti Tegal, 2020.

[8] S. E. Juliansyah Noor, Metodologi Penelitian: Skripsi, Tesis, Disertasi \& Karya Ilmiah. Prenada Media, 2016.

[9] Z. Arifin, "Kriteria instrumen dalam suatu penelitian," J. Theorems (the Orig. Res. Math., vol. 2, no. 1, pp. 28-36, 2017.

[10] F. Nurrohma and E. A. Purnomo, "THE EFFECTIVENESS OF LEARNING VIDEOS TO IMPROVE STUDENTSMATHEMATIC COMMUNICATION SKILLS," EDUSAINTEK, vol. 4, 2020.

[11] E. Y. P. Nasution and P. Hayati, "Upaya Meningkatkan Kemampuan Komunikasi Matematis Siswa dengan Konteks Pandemi Covid-19 di MAN 1 Madina," Logaritma J. Ilmu-ilmu Pendidik. dan Sains, vol. 8, no. 02, pp. 131-144, 2020.

[12] F. Ferdianto, "Media Audio Visual Pada Kemampuan Komunikasi Matematis Siswa Kelas IX," Euclid, vol. 2, no. 2, 2016.

[13] D. Efendi, "Pengembangan Bahan Ajar Matematika dengan Model Discovery Learning untuk Mengembangkan Keterampilan Berpikir Kritis,” Eksponen, vol. 9, no. 1 , pp. 42-54, 2019.

[14] D. Hardianti, D. Desmayanasari, and N. Noprisa, "PROCESS ORIENTED GUIDED INQUIRY LEARNING, PEMBELAJARAN VAN HIELE, DAN KETERKAITANNYA,” Algoritm. J. Math. Educ., vol. 2, no. 1, pp. 47-58, 2020.

[15] D. Hardianti, "EFEKTIVITAS PENERAPAN MODEL PEMBELAJARAN KOOPERATIF TIPE NUMBERED HEADS TOGETHER DITINJAU DARI PEMAHAMAN KONSEP MATEMATIS SISWA (Studi pada Siswa Kelas VII 


\section{Hipotenusa}

Journal of Research Mathematics Education

VOL. 4 NO.2 2021

p-ISSN: 2621-0630

e-ISSN: 2723-486X

SMP Negeri 1 Rumbia Lampung Tengah Semester Genap Tahun Pelajaran 2014/2015).” Fakultas Keguruan dan Ilmu Pendidikan, 2015.

[16] D. Margaretha, F. Lestari, and D. Efendi, "Pengaruh Model Pembelajaran Think Talk Write (TTW) terhadap Kemampuan Pemecahan Masalah Matematis Peserta Didik," Hipotenusa J. Res. Math. Educ., vol. 3, no. 1, pp. 44-56, 2020. 